"Not for self, not for the fulfilment of any worldly material, desire or gain.... But solely for suffering of humanity.... I will treat and exel all."

- Charak Samhita

\title{
Medical Practice, Research and Ethics
}

Medical ethics basically means consideration of moral values as they apply to medicine. A need for ethical guidelines for physicians or health providers was felt in the ancient time as well. It has been detailed in Charak Samhita, by Hammurabi in Mesopotamia and by Hippocratus around $4^{\text {th }}$ century B.C.

The Hippocratic guidelines have been transformed into Hippocratic oath for Doctors. A new era of ethical guidelines were started after the fall of the Nazi Germany where gore experiments were carried out on prisoners and Jews including vivisections (ablative procedures and experiments on conscious and live persons). A trial famously known as The Doctor's Trial, which was carried out by American military court at Neuremberg (Germany) found many German doctors guilty of ethical crimes including Dr Carl Brandt and these doctors were awarded life imprisonment and death sentences.

In USA a patients bill of right was developed which elucidates the confidentiality of health information. Respectful and non discriminatory treatment of the patients. In Helsinki, the entire medical community and the jurists worked hard from 1964 to 1989 and developed the ethical guidelines known as "Helsinki declaration". In 1991, WHO finally developed a very elaborate guideline epidemiological researches. In crux the ethical principle revolves around the principle of beneficence (benefit to patient) and principle of non malfeasance (no harm to the research participant).

It is extremely important for medical practitioners and health providers and research workers to understand the basic tenets of the ethical guidelines individually adopted by different countries otherwise, an ugly situation may have to be faced by the health personnel \& research workers as many ethical guidelines, if broken are legally punishable.

Prof. S. M. Mishra

MS(Surgery), MS(Ortho), FRCS Editor In Chief 